\title{
Effect of stress-like concentrations of cortisol on follicular development and the preovulatory surge of $\mathrm{LH}$ in sheep
}

\author{
C. A. Daley*, M. S. Macfarlane, H. Sakurai and T. E. Adams ${ }^{\dagger}$ \\ Department of Animal Science, University of California, Davis, CA 95616, USA
}

\begin{abstract}
Stress-like concentrations of cortisol increase the negative feedback potency of oestradiol in castrated male sheep. A similar cortisol-dependent response in female sheep might be expected to suppress gonadotrophin secretion and impair follicular development and ovulation. The oestrous activity of 21 female sheep was synchronized using progestogen-treated vaginal pessaries to test this hypothesis. Stress-like concentrations of cortisol $\left(60-70 \mathrm{ng} \mathrm{ml}^{-1}\right)$ were established by continuous infusion of cortisol $\left(80 \mu \mathrm{g} \mathrm{kg}^{-1} \mathrm{~h}^{-1} ; n=13\right)$ beginning 5 days before, and continuing for 5 days after, pessary removal. Control animals $(n=8)$ received a comparable volume of vehicle $(50 \%$ ethanol-saline) over the 10 day infusion period. Serum concentrations of oestradiol increased progressively in control sheep during the $48 \mathrm{~h}$ immediately after pessary removal. This increase in serum oestradiol was blocked or significantly attenuated in sheep receiving stress-like concentrations of cortisol. Preovulatory surge-like secretion of $\mathrm{LH}$ was apparent in control animals $58.5 \pm 2.1 \mathrm{~h}$ after pessary removal. In contrast, surge-like secretion of $\mathrm{LH}$ was not observed during the 5 days after pessary removal in $54 \%$ (7 of 13) of sheep receiving cortisol. Moreover, the onset of the surge was significantly delayed in the cortisol-treated ewes that showed surge-like secretion of LH during the infusion period. The ability of episodic pulses of exogenous GnRH to override the anti-gonadal effect of cortisol was examined in a second study. Oestrous activity of 12 ewes was synchronized using progestogen-containing pessaries as described above. Ewes were randomly assigned to one of three treatment groups $(n=4$ ewes per group). Animals received cortisol $\left(100 \mu \mathrm{g} \mathrm{kg}^{-1} \mathrm{~h}^{-1}\right.$; groups 1 and 2) or a comparable volume of vehicle (group 3 ) beginning 5 days before, and continuing for 2 days after, pessary removal. Pulses of GnRH ( $4 \mathrm{ng} \mathrm{kg}^{-1} \mathrm{~h}^{-1}$, i.v.; group 1) or saline (groups 2 and 3 ) at $1 \mathrm{~h}$ intervals were initiated at pessary removal and continued for $48 \mathrm{~h}$. Serum concentrations of oestradiol were not significantly increased after pessary removal in sheep receiving cortisol alone. Conversely, serum concentrations of oestradiol increased progressively during the $48 \mathrm{~h}$ after pessary removal in control ewes and in ewes receiving cortisol and $\mathrm{GnRH}$. At the end of infusion, serum concentrations of oestradiol did not differ $(P>0.05)$ between control $\left(7.7 \pm 0.8 \mathrm{pg} \mathrm{m}^{-1}\right)$ ewes and ewes receiving cortisol and episodic $\mathrm{GnRH}\left(6.4 \pm 1.3 \mathrm{pg} \mathrm{ml}^{-1}\right)$. Moreover, these values were significantly greater $(P<0.05)$ than the serum concentrations of oestradiol in animals receiving cortisol $\left(1.0 \pm 0.4 \mathrm{pg} \mathrm{ml}^{-1}\right)$ alone. Collectively, these data indicate stress-like concentrations of cortisol block or delay follicular development and the preovulatory surge of LH in sheep. In addition, episodic GnRH overrides cortisol-induced delay in follicular maturation.
\end{abstract}

\section{Introduction}

Prolonged stress, such as exposure to temperature extremes (Griffiths et al., 1970), excessive rainfall (Doney et al., 1973), transportation (Ehnert and Moberg, 1991; Smart et al., 1994) or repeated laparoscopy (Martin et al., 1981) delays or

'Current Address: School of Agriculture, California State University, Chico, CA 95929 , USA.

tCorrespondence.

Revised manuscript received 8 February 1999. suppresses oestrous behaviour and reduces ovulation rate in sheep. Physical and psychological stressors also activate the hypothalamo-pituitary-adrenal axis and lead to marked and persistent increase in serum concentrations of glucocorticoids (Caraty et al., 1990; Guillaume et al., 1992; Komesaroff and Funder, 1994; Minton, 1994). The augmented glucocorticoid secretion induced by stress may contribute to the reduction in fertility commonly associated with stress. Exogenous glucocorticoids suppress follicular growth and development and ovulation in rodents (Smith $e t$ Downloaded from Bioscientifica.com at 04/26/2023 12:16:29PM 
al., 1971; Baldwin and Sawyer, 1974; Baldwin, 1979), primates (Cunningham et al., 1978; Hayashi and Moberg, 1990) and some domestic species (Barb et al., 1982; Stoebel and Moberg, 1982).

In contrast, exogenous glucocorticoids do not suppress surge-like secretion of LH or ovulation in sheep (Moberg et al., 1981; Phillips and Clark, 1990). However, these studies used the synthetic glucocorticoid dexamethasone administered as a bolus once or twice a day. Reproductive function in sheep receiving physiological concentrations of cortisol itself has not been characterized fully. Stress-like concentrations of cortisol increase the negative feedback potency of oestradiol in castrated male sheep (Daley et al., 1999). In this research model, neither cortisol (60-80 $\left.\mathrm{ng} \mathrm{ml}^{-1}\right)$ nor oestradiol $\left(2-3 \mathrm{pg} \mathrm{ml}^{-1}\right)$ alone significantly affected the size or pattern of LH secretion, but the combination of cortisol and oestradiol decreased LH pulse frequency and reduced basal concentrations of $\mathrm{LH}$. This response is similar to the augmented feedback potency of oestradiol observed in castrated male (Sakurai et al., 1995) and female (Thomas et al., 1988; Joseph et al., 1992) sheep during the non-breeding season. The enhanced feedback potency of oestradiol during periods of increasing day length is a significant factor contributing to the interruption of follicular development and ovulation that is characteristic of female sheep during the anoestrous season (Goodman et al., 1981). It was postulated that cortisol-induced enhancement of the feedback potency of oestradiol would have a similar effect in female sheep during the normal breeding season.

In the present study, ovarian steroid production and the appearance and duration of the preovulatory surge of LH in sheep receiving stress-like concentrations of cortisol was examined. It was hypothesized that the marked and persistent increase in the serum concentration of cortisol that is characteristic of stress would impair ovarian steroidogenesis and delay the onset of surge-like secretion of LH. In addition, it was postulated that episodic administration of $\mathrm{GnRH}$ would reverse the anti-gonadal effect of cortisol.

A portion of these studies was presented at the 30 th Annual Meeting of the Society for the Study of Reproduction, Portland, OR, USA, 2-5 August, 1997.

\section{Materials and Methods}

\section{Animals}

The effect of stress-like concentrations of cortisol on follicular development and ovulation was assessed using mature cyclic Rambouillet ewes (mean body weight $=53 \pm$ $2 \mathrm{~kg}$ ). Ewes were maintained under natural lighting in an open-sided barn with free access to water and alfalfa hay. The studies described were conducted during November and early December, a period of high reproductive activity in sheep at this latitude $\left(38^{\circ} \mathrm{N}\right)$. All experimental procedures involving the use of animals were conducted in accordance with National Institutes of Health (NIH) Guidelines and were reviewed and approved by the Animal Use and Care Committee for the University of California.

\section{Cannulation}

Intravenous cannulae (Intramedic PE 190, Clay Adams, Parsippany, NJ) were placed in the right and left jugular veins and used for hormone infusion and blood collection, respectively. All cannulae were passed through a protective plastic tubing sheath along a halter and lead rope to the exterior of the animal holding area. Animals were freely mobile at the end of a $1 \mathrm{~m}$ lead. The cannulae were inserted 3 days before initiation of treatment to permit acclimation to the conditions of experimentation.

\section{Hormone delivery}

Cannulae for the delivery of cortisol or vehicle $(50 \%$ ethanol-saline) were connected to syringes placed in Harvard infusion pumps (Model 2265, Harvard Bioscience, South Natick, MA). Cortisol (Sigma Chemical Co., St Louis, $\mathrm{MO}$ ) or a comparable volume of vehicle was delivered by continuous infusion $\left(1.0-1.2 \mathrm{ml} \mathrm{h}^{-1}\right)$. In Expt 2, episodic delivery of $\mathrm{GnRH}$ ( $4 \mathrm{ng} \mathrm{kg}^{-1} \mathrm{~h}^{-1}$; Peninsula Labs, Inc., Belmont, CA) in saline was effected by connecting the infusion pump to an automatic timer (Chrontrol, Lindburg Enterprises, San Diego, CA) that was activated for $5 \mathrm{~min}$ each hour. A volume of $1 \mathrm{ml}$ was delivered during each pulse.

\section{Design of Experiment 1}

The oestrous activity of 21 ewes was synchronized using vaginal pessaries (Chrono-gest, Intervet International, Boxmeer) impregnated with a synthetic progestogen $(40 \mathrm{mg}$ flugestone acetate). Synchronization of follicular development and ovulation was effected by removal of the first pessary 14 days after insertion. Ten days after removal of the first pessary, ewes received a second pessary that remained in place for an additional 10 days. Use of the two pessary synchronization regimen ensured that the luteal phase preceding the period of experimentation was of uniform duration in all ewes. Ewes were randomly assigned to one of two treatments groups. Animals in groups 1 and 2 received cortisol ( $\left.80 \mu \mathrm{g} \mathrm{kg}^{-1} \mathrm{~h}^{-1} ; n=13\right)$ or vehicle $(n=8)$, respectively, beginning 5 days before, and continuing for 5 days after, removal of the second vaginal pessary (pessary removal). Blood samples were collected once a day before pessary removal. Samples were collected at $3 \mathrm{~h}$ intervals beginning at pessary removal and continuing to the end of infusion. Blood was allowed to clot on ice. Serum was removed within $24 \mathrm{~h}$ of sample collection, rapidly frozen, and stored at $-20^{\circ} \mathrm{C}$ for later endocrine analysis.

\section{Design of Experiment 2}

The oestrous activity of 12 ewes was synchronized using progestogen-containing pessaries as described above. Ewes were randomly assigned to one of three treatments groups ( $n=4$ ewes per group). Animals received cortisol $(100 \mu \mathrm{g}$ $\mathrm{kg}^{-1} \mathrm{~h}^{-1}$; groups 1 and 2) or a comparable volume of vehicle 


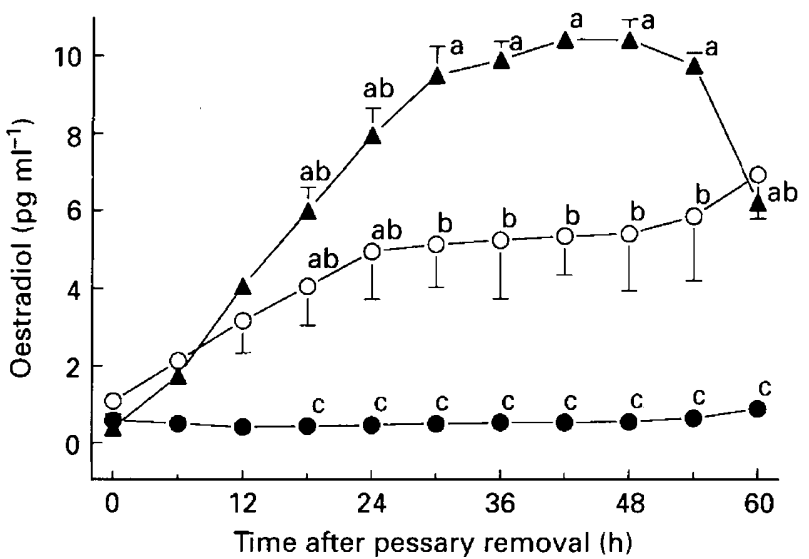

Fig. 1. Serum concentrations of oestradiol during the $60 \mathrm{~h}$ immediately after pessary removal in sheep receiving cortisol $\{80 \mu \mathrm{g}$ $\left.\mathrm{kg}^{-1} \mathrm{~h}^{-1} ; \mathbf{O}, \bigcirc\right)$ or a comparable volume of vehicle $(n=8 ; \boldsymbol{\Delta})$. Sheep receiving cortisol were divided into those that did $(n=6 ; 0)$ and those that did not $(n=7 ; 0)$ display preovulatory surge-like secretion of LH during the 5 days after pessary removal. At each time point, treatment means with different superscripts are significantly different $(P<0.05)$. Mean values not marked with a superscript are not significantly different $(P>0.05)$.

(group 3) beginning 5 days before, and continuing for 2 days after, pessary removal. Animals received pulses of $\mathrm{GnRH}$ (4 $\mathrm{ng} \mathrm{kg}^{-1} \mathrm{~h}^{-1}$; group 1) or saline (groups 2 and 3 ) at $1 \mathrm{~h}$ intervals beginning at pessary removal and continuing for 2 days. Blood samples were collected at $6 \mathrm{~h}$ intervals beginning at pessary removal and continuing to the end of infusion. Blood was allowed to clot on ice. Serum was collected and stored as described earlier.

\section{Hormone analysis}

Serum concentrations of $\mathrm{LH}$, oestradiol and cortisol were determined using validated procedures (Adams et al., 1975; Sakurai et al., 1992; Daley et al., 1999). The LH (NIAMDDoLH-26) reference standard was a gift from the National Hormone and Pituitary Program (Baltimore, MD). In all cases, intra- and interassay coefficients of variation were $<10 \%$. The minimum sensitivity of the $\mathrm{LH}$, oestradiol and cortisol assays was $0.2 \mathrm{ng} \mathrm{ml}^{-1}, 0.6 \mathrm{pg} \mathrm{ml}^{-1}$ and $1 \mathrm{ng} \mathrm{ml}^{-1}$, respectively.

\section{Statistical analyses}

Statistical significance of treatments was assessed by ANOVA. When significant treatment effects were observed, mean comparisons were made using Duncan's multiplerange test. Data are presented as mean \pm SEM. Chi-squared analysis was used to determine the significance of differences among treatments in the number of ewes displaying surge-like secretion of LH (Gill, 1978).

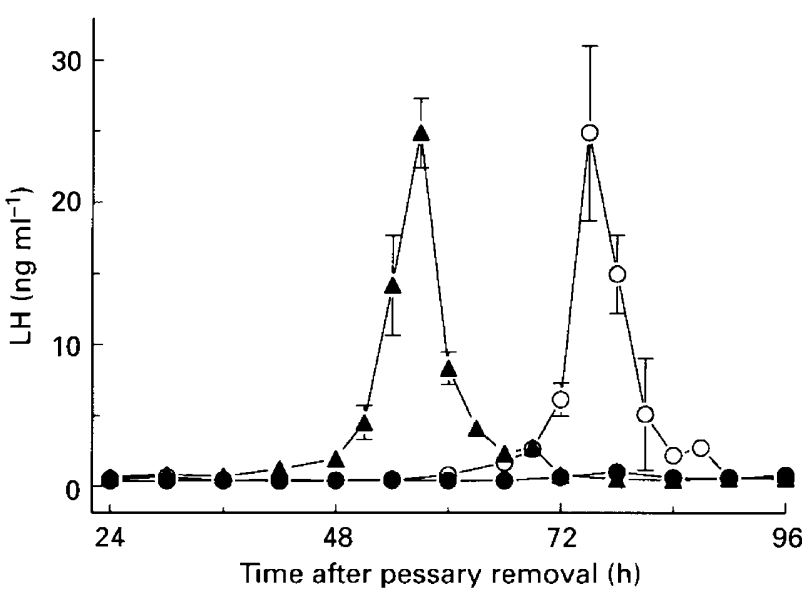

Fig. 2. Serum concentrations of LH after pessary removal in sheep receiving cortisol $\left(80 \mu \mathrm{g} \mathrm{kg} \mathrm{h}^{-1} \mathrm{~h}^{-1} ; 0,0\right)$ or a comparable volume of vehicle $(n=8 ; \boldsymbol{\Delta})$. Sheep receiving cortisol were divided into those that did $(n=6 ; 0)$ and those that did not $(n=7 ; 0)$ display preovulatory surge-like secretion of LH during the 5 days after pessary removal. The LH profile for those sheep displaying surgelike release of $\mathrm{LH}$ has been adjusted so that the $\mathrm{LH}$ peak for individual sheep is aligned with the average time interval from pessary removal to surge peak that is characteristic of each specific treatment group (58.5 and $74.3 \mathrm{~h}$ after pessary removal for sheep receiving vehicle and cortisol, respectively).

\section{Results}

\section{Experiment 1}

Serum concentrations of cortisol in ewes receiving vehicle alone did not differ from the pretreatment concentration $\left(18 \pm 4 \mathrm{ng} \mathrm{ml}^{-1}\right)$. Conversely, the serum concentration of cortisol was increased to $64 \pm 9 \mathrm{ng} \mathrm{ml}^{-1}$ within $24 \mathrm{~h}$ of initiation of infusion in ewes receiving exogenous cortisol at $80 \mu \mathrm{g} \mathrm{kg}^{-1} \mathrm{~h}^{-1}$. This serum concentration of cortisol was maintained for the remainder of the infusion period. Final serum concentrations of cortisol were $67 \pm 10$ and $18 \pm 3 \mathrm{ng}$ $\mathrm{ml}^{-1}$ in ewes receiving cortisol and vehicle, respectively.

The serum concentration of oestradiol was $0.7 \pm 0.2 \mathrm{pg}$ $\mathrm{ml}^{-1}$ at pessary removal and did not $\operatorname{differ}(P>0.05)$ between ewes receiving cortisol or vehicle alone. Mean serum concentrations of oestradiol in ewes receiving vehicle increased progressively during the period immediately after pessary removal, reaching a maximum concentration of $10.4 \pm 0.5 \mathrm{pg} \mathrm{ml}^{-1}$ at $48 \mathrm{~h}$ after pessary removal (Fig. 1). In contrast, continuous infusion of cortisol suppressed $(P<0.05)$ serum concentrations of oestradiol during the period after pessary removal. Serum oestradiol was maintained at basal concentrations $\left(<0.7 \mathrm{pg} \mathrm{ml}^{-1}\right.$ ) throughout the 5 days after pessary removal in 7 of 13 animals receiving stress-like concentrations of cortisol. Serum concentrations of oestradiol were increased progressively during the $24 \mathrm{~h}$ immediately after pessary removal in the remaining cortisol-treated animals (6 of 13 ). However, serum concentrations of oestradiol 24-48 h after pessary removal were significantly $(P<0.05)$ lower than concentrations in control animals. 
Table 1. Effect of continuous infusion of cortisol $\left(80 \mu \mathrm{gg}^{-1} \mathrm{~h}^{-1}\right)$ or a comparable volume of vehicle $(50 \%$ ethanol-saline) on the onset and size of the preovulatory LH surge in sheep

\begin{tabular}{lccccc}
\hline Treatment & $n$ & $\begin{array}{c}\text { Sheep displaying surge- } \\
\text { like release of } \mathrm{LH}^{\mathrm{a}}\end{array}$ & $\begin{array}{c}\text { Interval to } \mathrm{LH} \\
\text { surge }(\mathrm{h})^{\mathrm{b}}\end{array}$ & $\begin{array}{c}\text { Duration of } \\
\text { LH surge }(\mathrm{h})^{\mathrm{c}}\end{array}$ & $\begin{array}{c}\text { Size of LH surge } \\
\left(\mathrm{ng} \mathrm{ml} \mathbf{~}^{-1}\right)^{\mathrm{d}}\end{array}$ \\
\hline Vehicle & 8 & 8 & $58.5 \pm 2.1^{\mathrm{e}}$ & $11.9 \pm 0.9$ & $24.8 \pm 2.4$ \\
Cortisol & 13 & 6 & $74.3 \pm 6.6^{\dagger}$ & $10.5 \pm 0.6$ & $24.8 \pm 6.1$ \\
\hline
\end{tabular}

"Number of ewes displaying a preovulatory surge-like secretion of LH during the 5 days after pessary removal.

${ }^{b}$ Interval from pessary removal to the peak of the LH surge.

'Interval during the surge when serum concentrations of $\mathrm{LH}$ exceeded $2 \mathrm{ng} \mathrm{ml} \mathrm{m}^{-1}$.

'Serum concentration of $\mathrm{LH}$ at the peak of the surge.

ef Values within a column that do not share a common superscript are significantly different $(P<0.05)$.

Preovulatory surge-like secretion of $\mathrm{LH}$ was evident in all control ewes $(8$ of 8 ) receiving vehicle alone, and the peak of the surge was apparent $58.5 \pm 2.1 \mathrm{~h}$ after pessary removal (Fig. 2). In contrast, continuous infusion of cortisol blocked or delayed the appearance of the surge-like secretion of LH. Preovulatory surge-like secretion of LH was only apparent in cortisol-treated sheep ( 6 of 13) in which serum oestradiol was significantly increased during the period after pessary removal. Among cortisol-treated sheep displaying an ovulatory surge, the duration and size of the surge did not differ from the surge in control sheep. However, the interval from pessary removal to the peak of the surge was significantly $(P<0.05)$ extended $(74.3 \pm 6.6 \mathrm{~h}$ after pessary removal) relative to the size and timing of the surge in control animals (Table 1). Similar to serum concentrations of oestradiol, serum concentrations of LH in the remaining cortisol-treated sheep (7 of 13) did not increase above basal concentrations $\left(<1 \mathrm{ng} \mathrm{ml}^{-1}\right)$ during the period after pessary removal.

\section{Experiment 2}

Continuous infusion of cortisol at a rate of $100 \mathrm{~g} \mathrm{~kg} \mathrm{k}^{-1} \mathrm{~h}^{-1}$ increased serum concentrations of cortisol to $83.0 \pm 6.0 \mathrm{ng}$ $\mathrm{ml}^{-1}$ at $24 \mathrm{~h}$ after the start of infusion. Serum cortisol was maintained at this concentration for the remainder of the infusion period. In contrast, serum concentrations of cortisol in control animals receiving vehicle alone were $15.2 \pm$ $3.4 \mathrm{ng} \mathrm{ml}^{-1}$.

Serum concentrations of oestradiol increased progressively during the period after pessary removal in ewes receiving vehicle alone (Fig. 3). In contrast, serum oestradiol was maintained at basal concentrations in ewes receiving stress-like concentrations of cortisol. Concurrent episodic administration of GnRH reactivated follicular development and oestradiol secretion in cortisol-treated sheep. Serum concentrations of oestradiol at $48 \mathrm{~h}$ after pessary removal did not differ $(P>0.05)$ between control ewes $\left(7.7 \pm 0.8 \mathrm{pg} \mathrm{ml}^{-1}\right)$ and ewes receiving cortisol and episodic GnRH $\left(6.4 \pm 1.3 \mathrm{pg} \mathrm{ml}^{-1}\right)$. These values were significantly greater $(P<0.05)$ than the serum concentrations of oestradiol observed in animals receiving cortisol alone (1.0 $\pm 0.4 \mathrm{pg} \mathrm{ml}^{-1}$ ).

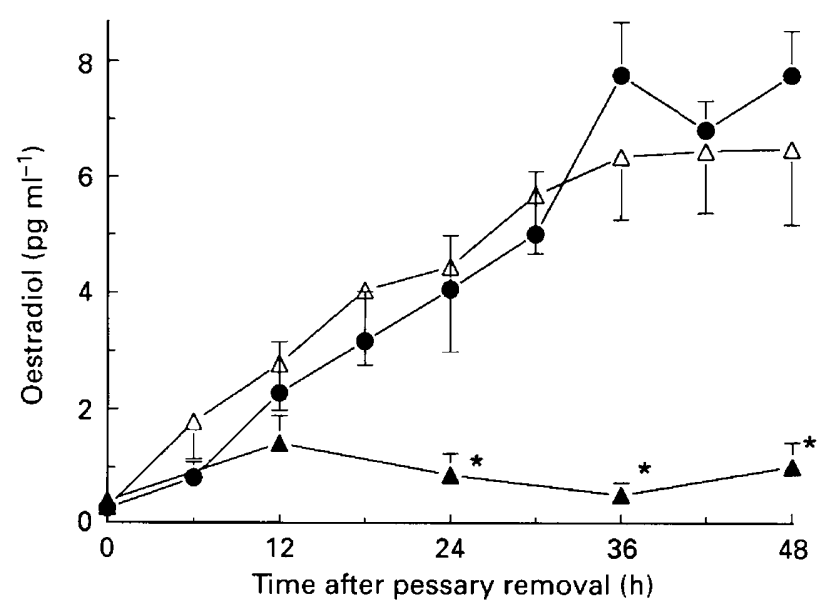

Fig. 3. Serum concentrations of oestradiol during the $48 \mathrm{~h}$ after pessary removal in sheep ( $n=4$ ewes per group) receiving cortisol $\left(100 \mu \mathrm{g} \mathrm{kg}^{-1} \mathrm{~h}^{-1} ; \mathbf{\Lambda}, \triangle\right)$ or a comparable volume of vehicle (O) beginning 5 days before, and continuing for $48 \mathrm{~h}$ after, pessary removal. Sheep received pulses of $\mathrm{GnRH}\left(4 \mathrm{ng} \mathrm{kg}^{-1} \mathrm{~h}^{-1}\right.$, i.v.; $\left.\Delta\right)$ or saline $(\Lambda$,$) at 1 \mathrm{~h}$ intervals during the $48 \mathrm{~h}$ after pessary removal. At each time point, treatment means denoted with an asterisk are significantly different $(P<0.05)$ from the other mean values at that time point.

\section{Discussion}

These results demonstrate that continuous administration of stress-like concentrations of cortisol to sheep during the late luteal and early follicular phases of the reproductive cycle suppresses oestradiol secretion and, presumably, follicular growth and development. Similarly, preovulatory surge-like secretion of LH is also blocked in more than $50 \%$ of cortisoltreated sheep. Moreover, the onset of the surge is significantly delayed in cortisol-treated sheep that show a surge of LH. Collectively, these observations indicate that stress-like concentrations of cortisol suppress ovarian function in sheep. This anti-ovulatory effect of cortisol is consistent with the response to exogenous glucocorticoid reported in women (Cunningham et al., 1978), rodents (Baldwin and Sawyer, 1974), and other domestic species (Barb et al., 1982; Stoebel and Moberg, 1982). However, these 
results differ from the findings of Phillips and Clarke (1990) which indicated that administration of a synthetic glucocorticoid once a day did not compromise follicular development or ovulation in sheep. Although the physiological basis for this discrepancy is not clear, differences in the type (dexamethasone versus cortisol), method of administration (bolus once a day versus continuous infusion) or dose (2 mg DEX day-1 versus $2 \mathrm{mg}$ cortisol kg-1 day ${ }^{-1}$ ) of glucocorticoid may be contributory factors.

In the present study, attempts were made to approximate the marked and persistent increase in the serum concentration of cortisol that is observed in sheep during exposure to repetitive or persistent stress by infusion of the natural glucocorticoid. Continuous infusion of cortisol at rates of $80-100 \mu \mathrm{g} \mathrm{kg}^{-1} \mathrm{~h}^{-1}$ established serum concentrations of cortisol comparable with those in sheep during exposure to moderate stressors, such as transportation, repeated laparoscopy, or isolation and restraint (Martin et al., 1981; Ehnert and Moberg, 1991; Minton, 1994). Use of the natural glucocorticoid at physiological concentrations strengthens the conclusion that stress-like concentrations of cortisol impair fertility in sheep.

As observed in control animals, serum oestradiol concentrations increase progressively during the normal follicular phase and reach a peak just before the ovulatory surge of LH (Webb and England, 1982; Sakurai et al., 1992; Scaramuzzi et al., 1993). Large preovulatory follicles are the primary source of the steroid and little oestradiol is produced by small or atretic follicles (Carson et al., 1981). Therefore, serum concentrations of oestradiol can provide an approximate measure of follicular maturation. In contrast to the process of follicular development and ovulation in control animals, ewes receiving stress-like concentrations of cortisol showed two alternate patterns of oestradiol secretion during the period after pessary removal. One group of animals failed to display a preovulatory LH surge and serum oestradiol was maintained at basal concentrations throughout the period of cortisol delivery. This is likely to reflect the absence of significant follicular growth during this period. Huet et al. (1997) reported that only ovine follicles larger than $3.5 \mathrm{~mm}$ in diameter acquired the capacity to synthesize oestradiol. The observations of the present study indicate that cortisol may arrest follicular development before that stage of maturation.

The alternate pattern of oestradiol secretion in cortisoltreated sheep was characterized by a gradual and progressive increase in the serum concentration of oestradiol. This may indicate that follicular development is retarded, but is not blocked completely. This contention is supported by the observation that an ovulatory surge of LH is apparent in this group of animals. However, both the progression of oestradiol secretion and the onset of the surge were significantly delayed relative to the temporal pattern observed in control animals.

The two patterns of oestradiol secretion in cortisol-treated sheep in the present study are similar to the two alternate responses to stress during the follicular phase of monkeys (Xiao et al., 1998). The physiological basis for these two patterns of follicular response, arrested or delayed development, is unclear and is currently the subject of investigation. Two alternate hypotheses may account for this variation between animals in the pattern of response. One hypothesis is that the stage of the follicular wave at which stress or stress-like concentrations of cortisol is introduced may influence the follicular response. Alternatively, the threshold of cortisol required to arrest follicular development fully may vary among sheep. According to this proposal, increasing the duration or extent of cortisol stimulation may increase the proportion of sheep showing full arrest of follicular development. In this regard, it is interesting to note that oestradiol secretion was suppressed in all ewes that received cortisol at $100 \mu \mathrm{g} \mathrm{kg}^{-1} \mathrm{~h}^{-1}$ (Expt 2), but in only $50 \%$ of ewes that received cortisol at $80 \mathrm{\mu g} \mathrm{kg}^{-1} \mathrm{~h}^{-1}$ (Expt 1).

Stress-like concentrations of cortisol may arrest or retard folliculogenesis by acting directly at ovarian loci. In vitro studies demonstrated that glucocorticoids compromise several key steps in follicular development and steroidogenesis in rodents (Schoonmaker and Erickson, 1983). Alternatively, cortisol may act at hypothalamic or hypophyseal sites to decrease gonadotrophin secretion and, thereby, limit the amount of LH and FSH available to support follicular development and ovulation.

This proposal is consistent with the findings of Daley et al. (1999) that the negative feedback potency of oestradiol is enhanced in orchidectomized sheep during concurrent exposure to high concentrations of cortisol. If stress-like concentrations of cortisol have a similar effect in female sheep, the effect is likely to be most prominent during the early follicular phase when a circhoral pattern of $\mathrm{GnRH}$ and gonadotrophin secretion supports follicular maturation. The critical role that circhoral secretion of GnRH plays in ovarian function is indicated by the arrest of follicular development after administration of a GnRH antagonist (Campbell et al., 1990) or immunoneutralization of endogenous GnRH (McNeilly et al., 1984; Sakurai et al., 1992). Similarly, follicular development and ovulation are reinstated during seasonal anoestrus by episodic delivery of GnRH (McLeod et al., 1982). The present study demonstrates that episodic administration of $\mathrm{GnRH}$ also reactivates follicular development and ovulation in sheep receiving stress-like concentrations of cortisol. This indicates that stress-like concentrations of cortisol decrease the activity of the GnRH pulse generating system. Similar actions of glucocorticoids at hypothalamic or hypophyseal loci have been observed in rodents (Baldwin and Sawyer, 1974) and women (Saketos et al., 1993). Similarly, the activity of the GnRH secretory apparatus is apparently decreased in sheep and primates during stress (Chen et al., 1992; Battaglia et al., 1998). It is postulated that the infertility induced by stress or stress-like concentrations of cortisol is due, at least in part, to a cortisoldependent increase in the negative feedback potency of oestradiol. During the follicular phase of the oestrous cycle the augmented negative feedback potency of oestradiol would be expected to suppress the frequency or amount of episodic release of $\mathrm{GnRH}$ and decrease gonadotrophin secretion below the threshold required to sustain the normal progression of follicular development.

This work was supported by USDA Grant 93-37203-9111 and the California Agricultural Experiment Station.

Downloaded from Bioscientifica.com at 04/26/2023 12:16:29PM 


\section{References}

Adams TE, Kinder JE, Chakraborty PK, Estergreen VL and Reeves JJ (1975) Ewe luteal function influenced by pulsatile administration of synthetic LHRH/FSHRH Endocrinology 97 1460-1467

Baldwin DM (1979) The effect of glucocorticoids on estrogen-dependent luteinizing hormone release in the ovariectomized rat and on gonadotropin secretion in the intact female rat Endocrinology 105 120-128

Baldwin DM and Sawyer CH (1974) Effects of dexamethasone on LH release and ovulation in the cyclic rat Endocrinology 94 1397-1403

Barb CR, Kraeling RR, Rampacek GB, Fonda ES and Kiser TE (1982) Inhibition of ovulation and LH secretion in the gilt after treatment with ACTH or hydrocortisone Journal of Reproduction and Fertility 64 85-92

Battaglia DF, Brown ME, Krasa HB, Thrun LA, Viguie C and Karsch FJ (1998) Systemic challenge with endotoxin stimulates corticotropin-releasing hormone and arginine vasopressin secretion into hypophyseal portal blood: coincidence with gonadotropin-releasing hormone suppression Endocrinology $1394175-4181$

Campbell BK, McNeilly AS, Picton HM and Baird DT (1990) The effect of a potent GnRH antagonist on ovarian secretion of oestradiol, inhibin and androstenedione and the concentration of LH and FSH during the follicular phase of the sheep oestrous cycle Journal of Endocrinology 126 377-384

Caraty A, Grino M, Locatelli A, Guillaume V, Boudouresque F, ConteDevoix B and Oliver C (1990) Insulin-induced hypoglycemia stimulates corticotropin-releasing factor and arginine vasopressin secretion into hypophyseal portal blood of conscious, unrestrained rams fournal of Clinical Investigation 85 1716-1721

Carson RS, Findlay JK, Clarke IJ and Burger HG (1981) Estradiol, testosterone, and androstenedione in ovine follicular fluid during growth and atresia of ovarian follicles Biology of Reproduction 24 105-113

Chen MD, O'Byrne KT, Chiappini SE, Hotchkiss J and Knobil E (1992) Hypoglycemic 'stress' and gonadotropin-releasing hormone pulse generator activity in the rhesus monkey: role of the ovary Neuroendocrinology 56 666-673

Cunningham GR, Goldzieher JW, de la Pena A and Oliver M (1978) The mechanism of ovulation inhibition by triamcinolone acetonide journal of Clinical Endocrinology and Metabolism 46 8-14

Daley CA, Sakurai H, Adams BM and Adams TE (1999) Effect of stress-like concentrations of cortisol on gonadotroph function in orchidectomized sheep Biology of Reproduction 60 158-163

Doney JM, Gunn RG and Griffiths JG (1973) The effect of premating stress on the onset of oestrus and on ovulation rate in Scottish blackface ewes journal of Reproduction and Fertility 35 381-384

Ehnert K and Moberg GP (1991) Disruption of estrous behavior in ewes by dexamethasone or management-related stress Journal of Animal Science 69 2988-2994

Gill JL (1978) Design and Analysis of Experiments in the Animal and Medical Sciences Iowa State University Press, Ames, IA

Goodman RL, Legan SJ, Ryan KD, Foster DL and Karsch FJ (1981) Importance of variations in behavioural and feedback actions of oestradiol to the control of seasonal breeding in the ewe Journal of Endocrinology 89 229-240

Griffiths JG, Gunn RG and Doney JM (1970) Fertility in Scottish blackface ewes as influenced by climatic stress Journal Agricultural Science $75485-495$

Guillaume V, Conte-Devolx B, Magnan E et al. (1992) Effect of chronic active immunization anti-corticotropin-releasing factor on the pituitary-adrenal function in the sheep Endocrinology 130 2291-2298

Hayashi KT and Moberg GP (1990) Influence of the hypothalamicpituitary-adrenal axis on the menstrual cycle and the pituitary responsiveness to estradiol in the female rhesus monkey (Macaca mulatta) Biology of Reproduction 42 260-265

Huet C, Monget P, Pisselet C and Monniaux D (1997) Changes in extracellular matrix components and steroidogenic enzymes during growth and atresia of ovarian follicles in the sheep Biology of Reproduction 56 1025-1034
Joseph IBJK, Currie WD and Rawlings NC (1992) Effects of time after ovariectomy, season and oestradiol on luteinizing hormone and folliclestimulating hormone secretion in ovariectomized ewes journal of Reproduction and Fertility 94 511-523

Komesaroff PA and Funder JW (1994) Differential glucocorticoid effects on catecholamine responses to stress American Journal of Physiology 266 E118-E128

McLeod BJ, Haresign W and Lamming GE (1982) Induction of ovulation and luteal function in seasonally anoestrous ewes treated with small-dose multiple injections of GnRH Journal of Reproduction and Fertility 65 215-221

McNeilly AS, Fraser HM and Baird DT (1984) Effect of immunoneutralization of $\mathrm{LH}$ releasing hormone on $\mathrm{LH}, \mathrm{FSH}$ and ovarian steroid secretion in the preovulatory phase of the oestrous cycle in the ewe Journal of Endocrinology $101213-219$

Martin GB, Oldham CM and Lindsay DR (1981) Effect of stress due to laparoscopy on plasma cortisol levels, the preovulatory surge of $\mathrm{LH}$, and ovulation in the ewe Theriogenology 16 39-44

Minton JE (1994) Function of the hypothalamic-pituitary-adrenal axis and the sympathetic nervous system in models of acute stress in domestic farm animals Journal of Animal Science 72 1891-1898

Moberg GP, Watson JG, Stoebel DP and Cook R (1981) Effect of cortisol and dexamethasone on the oestrogen-induced release of luteinizing hormone in the anoestrous ewe Journal of Endocrinology $90221-225$

Phillips DJ and Clarke IJ (1990) Effects of the synthetic glucocorticoid dexamethasone on reproductive function in the ewe Journal of Endocrinology $126289-295$

Saketos M, Sharma N and Santoro NF (1993) Suppression of the hypothalamicpituitary-ovarian axis in normal women by glucocorticoids Biology of Reproduction 49 1270-1276

Sakurai H, Adams BM and Adams TE (1992) Pattern of gonadotropinreleasing hormone $(\mathrm{GnRH})$-like stimuli sufficient to induce follicular growth and ovulation in ewes passively immunized against GnRH Biology of Reproduction 47 177-184

Sakurai H, Adams BM and Adams TE (1995) Gonadotroph responsiveness in orchidectomized sheep. IV. Effect of estradiol infusion during the breeding and anestrous seasons Biology of Reproduction 52 382-389

Scaramuzzi RJ, Adams NR, Baird DT et al. (1993) A model for follicle selection and the determination of ovulation rate in the ewe Reproduction, Fertility and Development 5 459-478

Schoonmaker JN and Erickson GF (1983) Glucocorticoid modulation of follicle-stimulating hormone-mediated granulosa cell differentiation Endocrinology 113 1356-1363

Smart D, Forhead AJ, Smith RF and Dobson H (1994) Transport stress delays the oestradiol-induced LH surge by a non-opioidergic mechanism in the early postpartum ewe Journal of Endocrinology $142447-451$

Smith ER, Johnson J, Weick RF, Levine S and Davidson JM (1971) Inhibition of the reproductive system in immature rats by intracerebral implantation of cortisol Neuroendocrinology 8 94-106

Stoebel DP and Moberg GP (1982) Effect of adrenocorticotropin and cortisol on luteinizing hormone surge and estrous behavior of cows Journal of Dairy Science 65 1016-1024

Thomas GB, Pearce DT, Oldham CM, Martin GB and Lindsay DR (1988) Effects of breed, ovarian steroids and season on the pulsatile secretion of $\mathrm{LH}$ in ovariectomized ewes journal of Reproduction and Fertility 84 313-324

Webb R and England BG (1982) Identification of the ovulatory follicle in the ewe: associated changes in follicular size, thecal and granulosa cell luteinizing hormone receptors, antral fluid steroids, and circulating hormones during the preovulatory period Endocrinology 110 873-881

Xiao E, Xia-Zhang L, Barth A, Zhu J and Ferin M (1998) Stress and the menstrual cycle: relevance of cycle quality in the short- and long-term response to a 5-day endotoxin challenge during the follicular phase in the rhesus monkey Journal of Clinical Endocrinology and Metabolism 83 2454-2460 